\title{
PROVOCATION
}

\section{Discouraging children from speaking te reo in schools as a strategic Māori initiative}

\author{
Te Kawehau Hoskins*t \\ Kimai Tocker* \\ Alison Jones*
}

\begin{abstract}
This article is written as a provocation. By re-examining the practice of discouraging children from speaking te reo Māori in schools, we challenge our students and other researchers to be alert to the ways in which Māori are often positioned in critical research. Many otherwise radical accounts that focus on Māori assimilation into a Western social order unwittingly take a coloniser-centric approach, inevitably representing Māori as passive non-agents. We ask: Whose actions and motivations are given most attention in our critiques of Māori experiences? And how are Māori positioned in our writing as a result? A Māori-centred narrative, we argue, focuses on Māori as agents, and gives attention to progressive Māori educational thought, and Māori relationality, strategy, determination and survival.
\end{abstract}

\section{Keywords}

corporal punishment, Native Schools, Māori language, agency, Māori-centred analysis

\section{Introduction}

This provocation is written mainly for our research students in the field of Māori education, many of whom, in their essays, routinely position Māori as "colonised" and "disadvantaged". We do not deny the truth of these observations; rather, we question the effect of seeing Māori primarily in these terms. When Māori are positioned as colonised, the coloniser is necessarily positioned as the agent. Our attention is on the coloniser. The dominant group again takes centre stage in our thinking.

It has been useful for many years to take this coloniser-centric approach. It has been encouraged by forms of powerful critical analysis that focus on the need to understand oppression in order to speak and act against it (Freire, 1985; G. H. Smith, 2005). But it is time to self-critically reposition Māori in our thinking and writing in education-not to underplay the profound effects of colonisation, but to understand Māori positively, as acting in Māori interests, using Māori ways of interacting, with Māori knowledge. This is a key aim of Kaupapa Māori theory and methodology (L. T. Smith, 2015), but students often mobilise Kaupapa Māori theory as a platform from which to critique colonising assimilation, rather than as an opportunity to identify, inhabit and build on

* Te Puna Wānanga, School of Māori and Indigenous Education, Faculty of Education and Social Work, University of Auckland, New Zealand.

† Email: tk.hoskins@auckland.ac.nz 
mātauranga Māori and Māori ways of being and doing.

To illustrate our provocation, we return to a painful issue: the punishment of children for using their own language in Native Schools prior to the 1970s. We rely largely on rich stories from Māori in Ngà Kura Māori (Simon, 1998) and A Civilising Mission? (Simon \& Smith, 2001), as well as from Rachael Selby (1999), and Judith Manchester and Anne O'Rourke (1993). We also include the personal experiences of Kimai Tocker, one of this paper's authors.

\section{A Māori-centred approach to English language use in schools}

A common critical approach to the enforcement of the English language in New Zealand Native Schools between 1860s and 1960s is to focus on its assimilatory intentions. It is usual to give attention to the fact that the state viewed compulsory instruction in English as "a vital aspect of achieving assimilation of Māori through schooling" (Barrington, 2008, p. 34). The focus is on the state's oppressive power. The attention is on the coloniser. A coloniser-centred view becomes clear when we ask who are the actors in the assimilation narrative; that is, Who regarded English language as "assimilatory"?

What if we shifted our attention to the question of whether Māori saw the teaching of English as assimilatory or whether they wanted it because it suited their own purposes? Did they have good reasons for wanting to discourage Māori language use in the schools and encourage their children to learn English? In this provocation, we bypass the motivations and perspectives of the colonisers. We take a deliberately Māori-centric methodological approach to the practice of punishing children for speaking Māori in school. That is, we take an interest in Māori actions, giving attention to the Māori role in developing English-medium schooling in Aotearoa New Zealand. We see Māori communities not simply as victims of English-medium forces; our focus is on their active and strategic attempts to integrate new knowledges into their own, changing, universe.

This approach is an example of our provocation to see Māori as actively thoughtful in relation to the political and economic circumstances of their communities. In other words, we go beyond the idea that punishment for speaking Māori in schools can only be understood as a key colonising mechanism to assimilate Māori into the English-speaking world. Rather, taking seriously a Māori-centred perspective, we focus on the fact that, in taking up English, Māori attempted to assimilate aspects of the Pākehā world into their own.

Such an approach, to decentre Pākehā colonial motivation and to centre Māori strategic motivation, is potentially dangerous: it risks being seen as minimising the effects of colonisation, or even blaming the victim. We take it as read that Māori were, and remain, significantly disadvantaged and robbed by racist colonisation processes. But our interest is in Māori not as a people crushed by the great forces of global social change wrought by British imperialism, but as a people in active, ambivalent, sometimes positive and sometimes negative, engagement with Pākehā. The strength of this approach is that it is built on a presumption of mana Māori, celebrates Māori progressive thought, and gives attention to the complexities of the situation in which Māori communities found and find themselves as they faced and face te ao hurihuri.

A second methodological point relates to our approach to schooling. It is sometimes important to condemn schools for the damage they have done, and influential Māori scholars have been at the forefront of critiques of New Zealand schooling, particularly in regard to its being a tool of cultural assimilation (e.g., Bishop \& Glynn, 1999; Walker, 1990). But in this article (and alongside many other Māori researchers such as Bishop and Berryman [2010]) we choose to take seriously the significant positive value of schooling-particularly as understood by Māori. Schools function, supposedly, to serve a society through instilling proficiencies, such as reading and writing and maths (and now digital skills), needed for everyday life, as well as training children in positive social norms and cultivating self-confidence. Māori too often miss out on schooling's rewards. Widespread anxiety about Māori school success (see, e.g., Carpenter \& Osborne, 2014) reflects the ongoing inability of schooling to do its valuable job for Māori; significant education research funding is devoted to improving Māori school achievement for the simple reason that it is a necessary individual and social good.

\section{A Māori-centred approach to the first New Zealand schools}

To proceed with a Māori-centred analysis, we must start with the fact that Māori leaders invited schooling to New Zealand. The first schools were established 24 years before the Treaty of Waitangi, within the hapu of the north. These schools were enthusiastically supported by their communities, attended by Māori children, and the language 
of instruction was te reo Māori (Barrington \& Beaglehole, 1974; Jones \& Jenkins, 2011). Young rangatira taught the teachers to speak Māori, and assisted in compiling the first school books in Māori (Jones \& Jenkins, 2011, 2017).

The schools' establishment and longevity were haphazard, depending on the enthusiasm, attention and leadership of the host hapū as well as the availability of Māori-speaking Pākehā teachers. Yet many Māori who encountered these early schools were keen to learn the new technologies of reading and writing in both Māori and English. Even before 1820, the great Hongi Hika of Ngāpuhi was encouraging his own children to go to school. Māori leaders had clear aims of being part of the newly discovered wider world, on the same footing as the captains and political leaders they encountered on their travels to Australia and England (Jones \& Jenkins, 2011, 2017; Petrie, 2006). Māori were increasingly aware that reading and writing, and communicating in English, were keys to a better future, and in particular to the wealth that would accrue from trade.

But ultimately the schools did not deliver what Māori wanted. Māori leaders relied on the Māorispeaking missionaries as go-betweens, advisers and consultants in relation to the Pākehā commercial and political social order. This presented a problem. Māori sought an independent relationship with a secular world, but missionary teachers were reluctant to teach English and thereby grant Māori better access to that "ungodly" world. Furthermore, missionary teachers, most of whom were only modestly educated, were in no intellectual or social position to teach Māori what they wanted. So Māori leaders were dependent on teachers who were unwilling or unable to teach the technical skills needed by Māori or to impart the principles of what we now call trade, finance, law, diplomacy and all the English concepts Māori would need to enter into an informed, equitable and competitive relationship with Pākehā (Jones \& Jenkins, 2007; Petrie, 2006).

\section{Choosing our words for a Māori-centred analysis}

An important aspect of a Māori-centred methodology is our choice of words. The earliest schools, taught by missionaries, are commonly known as "mission schools". Historians apply this term-sometimes dismissively-to the schools in Aotearoa from 1816, when the first school opened, to when state-funded Native Schools were established in 1867. But for Māori, the schools were not understood in such terms. Whatever the aims of their missionary teachers, Māori did not attend school to be converted to Christianity; they went to school to learn to read and write-initially and necessarily in their own language, which was the language of New Zealand. In turn, the children taught their parents and others in the villages, and as a result literacy in te reo Māori in the north of New Zealand had become widespread by the 1830s (Parr, 1963). So, to call these early schools mission schools necessarily tells a Pākehā story. For Māori, they were just schools: institutions where modern technologies-reading and writing as well as cloth, sewing equipment and metal tools_could be accessed.

It is also worth reminding ourselves here that the use of the shorthand term "Māori" in articles such as this one, and many others, tends to homogenise iwi, hapū and whānau. Yet hapū engagement with schooling throughout the country was and is different; each area has its own specific educational history. Some hapū took to schooling with enthusiasm; others did not. Our argument here makes a general point, using information about common patterns of involvement with schools.

\section{Māori desire for high-quality schooling}

Māori communities continued to engage with schooling after New Zealand came under the control of the British Crown. In 1847, schools could have access to public funds, subject to certain conditions, one of which was that "instruction in the English language shall form a necessary part of the system" (Education Act 1847, cl. 3). The ordinance was intended for Māori children, who at that time made up the vast majority of schoolchildren in the country.

Many Māori communities were pleased about this shift towards English literacy. They had expressed disappointment with the missionaries for not teaching English (Jones \& Jenkins, 2011). Hapū had for many years provided land for their schools and maintained them. They considered these schools their own, and had high expectations (see stories in Simon \& Smith, 2001). When he got into Parliament in 1871, Karaitiana Takamoana (Ngāti Kahungunu) pushed for legislation requiring missionaries to return to the tribes the native land they had acquired for schools because their system had not benefited the children. He wanted Māori children to be taught in English only. He pointed out that the missionaries had been teaching the children "for many years, and the children are not educated. They have only taught them in the Māori language. The whole of the Maoris in this Island request that the Government should 
give instructions that the Maoris should be taught in English only" (Takamoana, 1871, p. 828).

Māori communities were intensely concerned about the quality of education in their schools. As reported in Ngā Kura Māori, in 1858, Ngāti Toa chiefs, having donated a lot of money and land for their school, requested "a really good English master to take charge of the school" (Simon, 1998, p. 8). Tribal leaders also wanted access to "higher" learning. Complaints came from Māori as early as the mid-1850s that the schools' industrial curriculum meant that the children were spending too much time outside in labouring tasks, such as ploughing, and not enough time in the classroom with their books (Simon, 1998, p. 11). Māori communities pointed out that they themselves can teach such things as ploughing: "We send the youths to you not to be taught what they can learn at home, but to teach them what they cannot get at home" (Royal Commission on the Te Aute and Wanganui School Trusts, 1906, p. 25).

There is no doubt that Māori wanted their children to gain European knowledge and language fluency primarily to assist tribes' dealings with Pākehā threats to Māori land. But Māori wished to be successful strategists in relation to the encroaching European world not just in defensive terms; they also wanted to enable their equitable sovereign engagement. Fluency in English and knowledge of European institutions and concepts were required and desired at this dangerous and potent point in their/our history. As Simon (1998) says, Māori embraced schooling “as a means of maintaining their sovereignty and enhancing their life chances" (p. 9). Put another way, good European schooling was seen as a means for Māori to broaden their existing knowledge and therefore to extend their Māori world, not diminish it.

\section{Māori demand for English language in schools}

The Māori demand for English was addressed by the 1867 Native Schools Act, which stated that "as far as practicable" English must be the medium of instruction to teach "the English language and the ordinary subjects of English primary education" (cl. 21) in a national system of secular schools located in Māori communities. In the Waikato and Taranaki, where the Land Wars had exacted their most terrible toll, Māori leaders were understandably slow to apply to the government for schools, or wanted nothing to do with the Pākehā (Barrington, 1971, p. 25). But in other regions, especially in the north and east, as well as in the South Island, communities eagerly offered land for Native Schools and, where they could afford it, money for the teachers as required by the Act. Schools in some areas flourished. In 1875, in the Hokianga district alone, 200-300 children were enrolled in Native Schools (Simon, 1998, p. 9).

Māori continued to want more than a basic education from their schools. This was the consistent message from the beginning, and it has not changed to the present day. At Kaipara, in 1871 , a leading rangatira said, "Let schools be established . . . that our children may be taught the English language and the other branches of education" (Barrington, 1971, p. 25). From the chief Te Mātenga in the Bay of Islands in 1873: "we have been taught three things - reading, writing and arithmetic. What we want is that education should be progressive ... we want more than these three things to enable our descendants to cope with the Europeans" (Simon, 1998, p. 12).

Wi Te Hakiro and 336 other Māori petitioned the government in 1876 asking for the schools to provide a "good sound education" in Māori interests, thereby repaying the tribes' efforts in supplying land and costs for the school. The petitioners argued for amendments to the Act so that there could be two different sorts of schools. In one, children who were fluent in te reo and tikanga would be taught in Māori; the other would be for Māori children from two years old, who, the petitioners argued, should be taught "the Pākehā language, and all the knowledge the Pākehā possess".

Ko nga tamariki katoa ka rua tau i te mea ka oroko timata ake ratou ki te korero, ko nga tamariki enei, e tau ana kia whakaakona ki te reo Pakeha, me era atu tini matauranga hoki au a te Pakeha. Ki te mea ia tenei koutou kei te hiahia kia akona tikatia a matou tamariki i runga i te nei te huarahi marama ngawari hoki kua whakaaria i runga ake nei, e hohoro ai a matou tamariki te whiwhi ki nga matauranga maha a te Pakeha. (Te Hakiro, 1876, p. 1)

Te Hakiro and the petitioners had the future in mind. As a result of this system, Māori children would soon be on an equal footing with Pākehā children in regard to their schooling: "kua rite tonu te matauranga o nga tamariki Maori ki nga tamariki Pakeha" (Te Hakiro, 1876, p. 2).

Following the Land Wars, Māori leaders, who felt keenly the urgency for advanced English competence in order to participate in the country's legal system, pressed for more schools. In 1877 , a petition tabled by Renata Kawepo and 790 
others, and Riripi Ropata and 200 others, asked for a wider provision of schools so that more Māori children could learn English. The petitioners maintained that there were "many great grievances of the Maoris remaining that require attention", including land laws, composition of juries and bad government. The petition read, in part, "Ko te Kawanatanga me kaha atu tana mahi ki te whakatu kura ki nga wahi katoa o te motu kia mohio ai nga tamariki Maori ki te reo Pakeha, ma tenei hoki ka rite ki te Pakeha ka mohio hoki ki nga mahi nana nei i whakanui te iwi Pakeha" ["The Government should use every endeavour to have schools established throughout the country, so that the Maori children may learn the English language, for by this they will be on the same footing as the Europeans, and will become acquainted with the means by which the Europeans have become great"] (Kawepo \& Ropata, 1877, p. 2).

Again, some argue that Kawepo and Ropata and their people's petition simply demonstrates their colonised thinking (e.g., Ka'ai-Mahuta, 2011, p. 204). But such Māori visions for schools can equally be seen as progressive and enlightened. Mãori believed that they could be Mãori and speak Māori as usual in the kāinga and harness the English language, by way of schooling, for Māori purposes. To use modern terminology, Māori understood very early they could be bilingual and bicultural, even if the Pākehā could not even begin to think in these terms for themselves.

\section{Māori language in the schools}

It is interesting to note that Māori language was not banned from all Native Schools, either officially or in practice. In 1880, no doubt influenced by Māori concerns about teacher quality, the government inspector returned to the "pre-war policy of bilingualism" (Barrington, 1966, p. 5). The 1880 Native Schools Code required teachers to demonstrate some competence in te reo (New Zealand Parliament House of Representatives, 1880, pp. 1-7) (as well as knowing about Māori "customs" and "the history of the New Zealand wars"), and allowed them to use Māori language in junior classes to assist the children's comprehension of English, though the teacher's ultimate aim was "to dispense with the use of Maori [in the classroom] as soon as possible" (New Zealand Parliament House of Representatives, 1880, p. 1). As well as showing some Māori language competence, teachers and teacher assistants in the Native Schools, whether they were Pākehā or Māori (the first Māori principal at a Native School was appointed in 1875, but Māori were teaching assistants from the beginning; Simon, 1998, p. 62), were required to be involved in the local communities. Native Schools were required to have school committees, composed of local Māori community members. Officially anyway, the schools were not expected to be Māori-language-free zones.

Nevertheless, some Māori did not agree. Te Hakiro's (1876) petition included the demand that neither Māori nor Pākehā children should speak Māori in the school playground; in addition, the teachers, they said, should be entirely ignorant of the Māori language, so that they would not default to Māori in the school.

kia kaua rawa aua tamariki Maori me aua tamariki Pakeha e whakarangona ki te tahi reo Maori kotahi-tahi-nei. Ko taua kaiwhakaako ratou ... hei te mea kuare rawa ki te reo Maori. (2)

One reason that a school for Māori boys, Te Aute College in Hawke's Bay, became particularly popular was the belief of the headmaster, John Thornton, that Māori boys should have access to higher education, as their parents wanted. $\mathrm{He}$ appeared in 1906 before a Royal Commission on Māori schooling. The school was established on 4000 acres of land gifted by Ngāi Te Whatuiāpiti. Reflecting views that Māori had long held, Thornton justified the teaching of higher academic subjects, including Latin, Euclidean geometry and algebra, to Māori boys by arguing that it would give them the potential to enter university: "I felt the Maoris should not be shut out from any chance of competing with English boys in the matter of higher education. I saw that the time would come when Maoris would wish to have their own doctors, their own lawyers and their own clergymen, and I felt it was only just to the race to provide facilities for their doing so, especially in an institution that was a Maori endowment" (as cited in Royal Commission on the Te Aute and Wanganui School Trusts, 1906, p. 32).

The students at Te Aute took their studies very seriously, Thornton said. They spoke English among themselves to such an extent that the teachers encouraged them to also speak Māori at school because "we do not want them to go back to their own people to be told, 'You have learned English and forgotten your own tongue." One of the commissioners opined that he did not think Māori would easily lose their "mother tongue" in New Zealand, to which Thornton replied, "They are losing it" (as cited in Royal Commission on the Te Aute and Wanganui School Trusts, 1906, p. 41). However, the vast majority of Māori children 
throughout the country still spoke only Māori at home.

\section{Māori practices aimed at school success}

Māori communities impatient for their children's school success intensified their efforts in relation to learning English. They often believed, as did the Department of Education, that speaking Māori in the playground reduced opportunities for practising what had been learned in the classroom. The department in 1917 published a booklet stating that the best way to learn English was through full immersion, with no translation and no Māori spoken: "The less [the students] hear of Māori, the better it will be for their English" (Department of Education, 1917, p. 6). Therefore, the reasoning went, children and their parents should be actively discouraged from speaking Māori anywhere inside the school gates. But no punishment for speaking te reo Māori was officially suggested, and the tone of the government reports is one of encouraging students rather than forcing them to speak English outside the classroom (New Zealand Parliament House of Representatives, 1906).

Even though the 1880 code did not rigidly insist on English language speaking inside the school gate, the practice of teachers, both Māori and Pākehā, was often a different matter. Some saw that the only way to improve English language skills was through compulsion. Patu Hohepa reports that the Waima School minutes referred (in Māori) to "the law forbidding the speaking of Māori in class or in the school grounds" (as cited in Simon \& Smith, 2001, p. 164) and declared that a parent or person speaking Māori at the school would be fined-as well as encouraging children to "inform" on that person. There was no such law; communities such as the Waima people simply wanted their children to do well at school. Some Māori communities remained hostile to the idea of learning English-particularly those who had lost land through confiscation (Barrington, 1971), but in most, although Māori remained the main language of communication in the kāinga, proficiency in English was seen as an essential skill for the children's future outside the villages.

One of the most significant public voices in the discussion about the speaking of English in Māori schools through the early decades of the 20th century was Āpirana Ngata of Ngāti Porou. A graduate of Te Aute College, the first Māori to graduate from the University of New Zealand, a lawyer and popular member of Parliament, Ngata in the 1930s was very concerned that schools were still not producing the results he wanted for the people. Like many before him, he believed that better proficiency in English was necessary. Proficiency in the English language, he argued, was "the key with which to open the door to the sciences, the mechanised world, and many other callings" (Ngata, as cited in Barrington 1966, p. 12). So he advocated placing an even greater emphasis on English language in the Māori primary schools. He was hugely influential among both Māori and Pākehā at a time when Māori spirits were at a low ebb. In many areas people were isolated and in poor health, still suffering from the traumatic and impoverishing effects of the Land Wars, the individualising legislation that restricted Māori land use, and the devastating loss of young Māori men in the First World War.

Ngata was a visionary, and knew that, at this point in their history, his people needed to be Māori but also master European technologies. His famous exhortation "E tipu e rea mō ngā rā o tō ao. Ko tō ringaringa ki ngā rākau a te Pākehā hei oranga mō tō tinana. Ko tō ngākau ki ngā taonga o $\bar{o}$ tipuna hei tikitiki mō tō mahunga. Ko tō wairua ki te Atua nāna nei ngā mea katoa" ["Grow, tender shoot, for the days of your world. Turn your hand to the tools of the Pākehā for the wellbeing of your body. Turn your heart to the treasures of your ancestors as a crown for your head. Give your soul unto God the author of all things"] (as cited in Walker, 2002, p. 397) was an inspiration to many Māori looking for a future in a world irrevocably altered by colonisation and Pākehā cultural dominance. Both English and Māori languages were to be rich resources for Māori. Ngata's enthusiasm for increasing the pressure on English language proficiency at the primary school was based on an unshakeable assumption that, while English was taught effectively in the schools, te reo Māori could and would prosper in the kāinga and on the marae, allowing Māori children to become, in effect, bilingual and bicultural.

\section{Māori rejection of coercive violence as a teaching method}

Many Māori parents rejected any violence by teachers towards their children. They might have accepted onerous physical tasks as punishment but, as it was reported in 1862, teachers were "obliged to be very careful. ... No correction, or at most, only a very slight box on the ear or slap on the hand. If corrected, they run away; their parents do not send them back again" (Inspectors of Native Schools, 1862, p. 20). An 1862 Native School report pointed out that "as Native parents never inflict chastisement upon an offending child ... [it] 
must seem strange and tyrannical" (Inspectors of Native Schools, 1862, p. 35). But by the 20th century, corporal punishment seems to have become accepted in at least some Native Schools. Mehira Solomon (1999) from Ngāti Porou, who went to Tikitiki Native School in the 1940s, remembers that "when we were smacked for speaking Māori at school, our parents accepted it at home" (p. 43). Eventually, even Māori teachers used the practice alongside their Pākehā colleagues. It was a truism in schooling at the time that to hit a school child was to show care for his or her welfare.

Dozens of adults today have heard their parents' and grandparents' bitter stories about being hit at school for speaking their language, a practice that traumatised some children for life, or turned others away from their language altogether. Here are comments from adults recalling their experiences at Native Schools during the 1930s and 1940s from Simon and Smith's (2001) research:

If we were heard talking Māori on the playground we would get the stick for it. Te Kao Native School. (p. 141)

We would be taken into the room and given a walloping that would leave marks on your hands and legs. When it stung your hands and legs you knew that [you] had to try hard not to speak the Māori language. Ruatoki Native School. (p. 142)

Not all Native Schools were so anxious or so militant. At some Native Schools, te reo Māori was allowed, even if it was not spoken often:

When I was at school I was never punished for speaking Māori. We spoke Māori in our little school in the playground but we were never strapped like some people say they were strapped for speaking Māori. Tūhara Native School. (p. 141)

At Rakaumangamanga we were able to talk to one another ... We weren't strapped for speaking Māori. Rakaumangamanga Native School. (p. 144)

It is easy to be critical today about hitting children for speaking their familiar language in the playground. But because some Māori leaders and families thought that the compulsion to practise only English at school was necessary for their children's future success, they asked the teachers to be strict with their children:

My grandfather went to school and told the teacher not to let us speak Māori. (p. 147)
I'm not condemning [English language compulsion] really. Because we needed to get into the European world to get a job ... I believe it [was instigated by] Ngata because he looked at ways and means of getting our Māori people to be able to attain what he achieved. (p. 146)

Most often, the attitude towards the teachers was: we supply the school, you do the job of teaching (p. 133). On the other hand, some children were kept away from school by whānau worried about the young becoming alienated from them as Māori. Patricia Grace (1998) remembers her grandmother saying that her father did not want her to go to school because he did not want her to learn English (p. 54).

In many more cases, whānau enthusiasm to support their children's success at school meant parents often took to speaking English in the home, although on the marae and in the churches, Māori language was always used. Kimai Tocker remembers that, during the 1950s and 1960s, her mother, a native speaker of te reo, rarely spoke Māori in front of her children. It was only when Kimai's parents wanted to speak privately that they resorted to te reo, so the children could not understand them. Her parents, both teachers in Native Schools (her Pākehā father spoke te reo), were influenced by the leaders of the time: English language fluency and academic achievement in English were seen as the routes to future success.

Many Māori parents worked hard to support their children's fluency in English. If English was practised at home, it was often perfect, but in some families English was spoken in a simple pidgin form, because the parents themselves had not had high-quality English language education. Such sincere efforts at speaking English had a perverse effect. Māori could not win: speaking poor English was frowned on by the teachers and others, such as Pākehā employers. But for some Māori, including Ngata (Walker, 2002) and the youthful Professor Hirini Moko Mead (1998), their communities and their schools helped them to be highly competent bilingual speakers, and influential in New Zealand thought and politics.

The experience of some, such as Te Aonohoriu Haig from Tokomaru Bay, epitomised the Māori bilingual ideal. Like Kimai's mother and others of that time, Haig grew up speaking Māori at home. She was encouraged by her aunties to learn English from her Pākehā neighbours, so "by the time I went to school I spoke two languages, Māori and English" (Haig, 1998, p. 40). It was assumed by whānau that both languages could be sustained. 
As early as 1939, Ngata had noticed the loss of Māori language among his people, and he changed his views on education and the English language, saying that there was nothing worse than for a person to have Māori features without being able to speak the Māori language (as cited in Walker, 1990, p. 193).

But by the middle of the 20th century, as more pressures came on Māori to seek work among Pākehā, some inevitably began to lose sight of the value of te reo. After World War II, Māori began the great migration into towns for work, and speaking English quickly came to be seen as more use than speaking Māori. For the young especially, te reo became the language of the past, of the old people, of the marae. Kimai and others of her generation growing up in the 1960s and 1970s were busy following the high educational goals set by their parents. But doing well in school and university did not involve speaking Māori. When Richard Benton (1997) and others surveyed more than 33,000 Māori in the North Island on Māori language use in the 1970s, he alerted everyone to the fact that "English had become the lingua franca of Maoridom as a whole" and that the language was in grave danger (p. 23). Few Māori could have predicted that te reo would get lost, or what the effects of that loss might be.

Kimai's parents believed that childhood and youth were to be spent gaining academic success (only available in English), and they were confident that their children would, in time, learn the Māori language and culture. Of eight Tocker siblings, Kimai was the only one who returned to learn the language as an adult. Kimai's mother expressed regret in her later life, as she watched her daughter struggle to learn te reo, that she failed to teach her children the language. Her mother tongue was Māori, and as a confident Māori woman who also spoke eloquent English, she wanted this powerful dual competency for her children. She could not have foreseen that the language would be lost from the community-that it would not always be there, ready to be picked up again (Tocker, 2014, 2017).

\section{Conclusion}

This provocation has illustrated how Māori can and should be understood as strategic actors in educational history. We have demonstrated how a Māori-centred point of view can work to maintain a positive discourse about Māori strategic encounters with the colonisers, in the face of difficult choices. Our attention has been on Māori communities rather than on the colonisers.

Some might insist on seeing Māori parents and communities who discouraged their children's use of te reo in schoolyards as colonised into believing that the future was in English, or believe they were pawns of Pākehā assimilation. Or, they might agree with Walker (1990) that Māori leaders only complied with school policy because "they did not fully understand the role of an education system in cultural reproduction and its power to implement the official policy of assimilation” (p. 193).

We maintain that to say it was simply the fault of the Pākehā coloniser's system has the effect of disempowering Māori. A coloniser-centric perspective positions the teachers, inspectors and policymakers as the only people with agency and power-thereby rendering Māori communities always-already victims, devoid of authority, resistance, strategic engagement and mana. The history of language loss is the history of colonisation, and vice versa, but our accounts of that history do not need to position Indigenous people as invisible, naīve, incompetent or duped. A Māori-centred account recognises that Māori were (and are) key actors in New Zealand schooling, responding flexibly and strategically to meet global social change and the future, in what they understood as their own interests.

\section{Glossary}

Aotearoa

Māori name for New Zealand; lit., "land of the long white cloud"

hapū sub-tribe(s) that share a common ancestor

iwi

kāinga

Kaupapa Māori

tribal kin group; nation

home

Māori way of doing things

mana

power, authority

marae tribal meeting grounds

mātauranga Māori

Māori knowledge

Pākehā

people of predominantly European descent

rangatira chief

te ao hurihuri

the changing world

te reo Māori

tikanga

the Māori language

whānau

customs and practices

family, extended family

\section{References}

Barrington, J. M. (1966). Maori scholastic achievement: A historical review of policies and provisions. New Zealand Journal of Educational Studies, 1(1), 1-14. Barrington, J. M. (1971). Maori attitudes to Pakeha institutions after the wars: A note on the establishment 
of schools. New Zealand Journal of Educational Studies, 6(1), 24-28.

Barrington, J. M. (2008). Separate but equal?: Maori schools and the Crown, 1867-1969. Victoria University Press.

Barrington, J. M., \& Beaglehole, T. H. (1974). Maori schools in a changing society: An historical review. New Zealand Council for Educational Research.

Benton, R. (1997). The Maori language: Dying or reviving? New Zealand Council for Educational Research.

Bishop, R., \& Berryman, M. (2010). Te Kotahitanga: Culturally responsive professional development for teachers. Teacher Development, 14(2), 173-187.

Bishop, R., \& Glynn, T. (1999). Culture counts: Changing power relations in education. Dunmore Press.

Carpenter, V., \& Osborne, S. (Eds.) (2014). Twelve thousand hours: Education and poverty in Aotearoa New Zealand. Dunmore Publishing.

Department of Education. (1917). The teaching of English in Native Schools: The Direct, or Natural, Method. National Library ATL PAM No. 3974.

Education Act 1847 (No. 10).

Freire, P. (1985). Pedagogy of the oppressed. Penguin.

Grace, P. (1998). Two worlds. In W. Ihimaera (Ed.), Growing up Māori (pp. 47-57). Tandem.

Haig, I. Te A. (1998). Titiro, moko! Whakarongo, moko! In W. Ihimaera (Ed.), Growing up Māori (pp. 40-46). Tandem.

Inspectors of Native Schools. (1862). Native Schools. Reports of Inspectors. In Appendix to the House of Representatives, (Sess. I, E-04), 1-40. National Library of New Zealand. http://atojs.natlib.govt.nz

Jones, A., \& Jenkins, K. (2007). Invitation and refusal: A reading of the beginnings of schooling in Aotearoa New Zealand. History of Education, 37(2), 187206. http://doi.org/ftpqmp

Jones, A., \& Jenkins, K. (2011). He kōrero: Words between us-First Māori-Pākehā conversations on paper. Huia Publishers.

Jones, A., \& Jenkins, K. K. (2017). Tuai: A traveller in two worlds. Bridget Williams Books. http://doi. org/d39r

Ka'ai-Mahuta, R. (2011). The impact of colonisation on te reo Māori: A critical review of the State education system. Te Kaharoa, 4(1), 195-225. http:// doi.org/c7cb

Kawepo, R., \& Ropata, P. (1877). Petitions of Renata Kawepo and 790 others, and Piripi Ropata and 200 others. In Appendix to the House of Representatives, (J-1), 1-4. National Library of New Zealand. http:// atojs.natlib.govt.nz

Manchester, J., \& O'Rourke, A. (1993). Liberating learning: Women as facilitators of learning. Manchester, J., O'Rourke A.

Mead, H. M. (1998). He kupu whakataki: Foreword. In J. Simon (Ed.), Ngā kura Māori: The Native Schools system 1867-1969 (pp. viii-xi). Auckland University Press.
Native Schools Act 1867.

New Zealand Parliament House of Representatives. (1880). Education: Native Schools. In Appendix to the House of Representatives, (Sess. I, H-01f), 1-7. National Library of New Zealand. http://atojs. natlib.govt.nz

New Zealand Parliament House of Representatives. (1906). Education: Native Schools (In continuation of E.-2, 1905.). In Appendix to the House of Representatives, (Sess. II E-02), 1-37. National Library of New Zealand. http://atojs.natlib.govt.nz Parr, C. J. (1963). Maori Literacy, 1843-1867. Journal of the Polynesian Society, 72, 211-234.

Petrie, H. (2006). Chiefs of industry: Māori tribal enterprise in early colonial New Zealand. Auckland University Press.

Royal Commission on the Te Aute and Wanganui School Trusts. (1906). Te Aute and Wanganui School Trusts. (Report and evidence of the Royal Commission on the). In Appendix to the House of Representatives, (Sess. II, G-05), 1-50. National Library of New Zealand. http://atojs.natlib.govt.nz Selby, R. (Ed.) (1999). Still being punished. Huia Publishers.

Simon, J. (Ed.) (1998). Ngā kura Māori: The Native Schools system 1867-1969. Auckland University Press.

Simon, J., \& Smith, L. T. (Eds.) (2001). A civilising mission? Perceptions and representations of the New Zealand Native Schools system. Auckland University Press.

Smith, G. H. (2005). Beyond political literacy: From conscientization to transformative praxis. Counterpoints, 275, 29-42.

Smith, L. T. (2015). Kaupapa Māori research: Some kaupapa Māori principles. In L. Pihama, S. Tiakiwai, \& K. Southey (Eds.), Kaupapa rangahau: A reader (2nd ed., pp. 47-54). Te Kotahi Research Institute.

Solomon, M. (1999). Mehira's story. In R. Selby (Ed.) Still being punished (pp. 41-46). Huia Publishers.

Takamoana, K. (1871). New Zealand Parliamentary Debates, 11, 1-1107.

Te Hakiro, W. (1876). Petition of Wi Te Hakiro and 336 others. (Part of.). In Appendix to the House of Representatives, (Sess. I, J-04), 1-3. National Library of New Zealand. http://atojs.natlib.govt.nz

Tocker, K. (2014). Hei oranga Māori i te ao huriburi nei-Living as Māori in the world today: An account of kura kaupapa Māori [Unpublished EdD thesis]. University of Auckland.

Tocker, K. (2017). Living and learning as Māori: Language stories from three generations. Australian Journal of Indigenous Education, 46(1), 115-124. http://doi.org/d39s

Walker, R. (1990). Ka whawhai tonu mātou: Struggle without end. Penguin.

Walker, R. (2002). He Tipua: The life and times of Sir Appirana Ngata. Penguin. 